\title{
Orchard Floor Crops Reduce Growth of Young Pecan Trees
}

\author{
Wheeler G. Foshee ${ }^{1}$, William D. Goff ${ }^{1}$, Michael G. Patterson ${ }^{2}$, and \\ Donald M. Ball ${ }^{2}$ \\ Alabama Agricultural Experiment Station, Auburn University, AL 36849
}

\author{
Additional index words. Carya illinoensis, Carya illinoinensis, weed competition, cover \\ crops, legumes, grasses
}

\begin{abstract}
Hairy vetch (Vicia villosa Roth), common vetch (V. sativa L. 'Cahaba White'), arrowleaf clover (Trifolium vesiculosum Savi 'Yuchi'), crimson clover (T. incarnatum $L$. 'Tibbee'), red clover (T. pratense L. 'Redland II'), yellow nutsedge (Cyperus esculentus L.), buckwheat (Fagopyrum sagittatum Gilbert), hairy indigo (Indigofera hirsuta L.), bahiagrass (Paspalum notatum Flugge 'Pensacola'), common bermudagrass [Cynodon dactylon (L.) Pers.], and centipedegrass [Eremochloa ophiuroides (Munro) Hack] were grown for 3 years in a 3 $\times 3$-m spacing around young pecan [Carya illinoinensis (Wangenh.) K. Koch] trees. Compared to weed-free plots, all cover crops suppressed tree growth substantially, and there were no differences among cover crops in the degree of suppression. Mean trunk cross-sectional area of weed-free trees increased 26 -fold by the end of the third growing season but increased only 13-fold for trees grown with any cover crop. These results suggest that cover crops, if grown in young pecan orchards to promote beneficial insects, should be excluded from the immediate area around the young trees.
\end{abstract}

Growing cover crops in pecan orchards is a common practice, and benefits from cover crops are well documented: 1) increased $\mathrm{N}$ concentration in pecan leaves, 2) soil-improving organic matter (White, 1981), and 3) increase in predator insects for aphid suppression (Bugg et al., 1991). However, cover crops can affect pecan growth adversely by competing for water and nutrients (Blackmon, 1948; Hardy, 1939). Maintaining a weed-free surface under young pecan trees can increase tree growth compared to trees growing under weedy conditions (Patterson etal., 1991). Also, growth and yield of young pecan trees increases in weed-free plots compared to weedy plots (Patterson and Goff, 1994). In our study, we determined if commonly grown cover crops affect growth of young pecan trees.

\section{Materials and Methods}

Barerooted 'Desirable' pecan trees were planted in Winter 1991-92 on a $9.1 \times 10.7-\mathrm{m}$ spacing. The trees were drip-irrigated (two 7.6 liters/h emitters per tree) and were fertilized uniformly. The design was a randomized complete block with eight single-tree replications. There were 11 cover crops (Table 1) and a weed-free control. A $3 \times 3-\mathrm{m}$ area immediately around the tree was maintained for each

Received for publication 22 Dec. 1994. Accepted for publication 4 May 1995. Alabama Agricultural Expt. Station Journal Series no. 11-944818. Appreciation is expressed to James S. Bannon and James B. Witt for maintenance of the planting. The cost of publishing this paper was defrayed in part by the payment of page charges. Under postal regulations, this paper therefore must be hereby marked advertisement solely to indicate this fact.

${ }^{1}$ Dept. of Horticulture.

${ }^{2}$ Dept. of Agronomy.

HortScience, Vol. 30(5), August 1995 une and Aug. 1992. Weed control treatmer were confined to $3 \times 3-\mathrm{m}$ area centered on the tree. Weed-free plots were maintained similarly in 1993 and 1994. Cover crops were allowed to mature and were mowed during winter; some required an application of glyphoshate after maturation to control annual grasses that had germinated.

Trunk diameters were measured at a marked location $\approx 15 \mathrm{~cm}$ above ground level on May to Sept. 1992, Mar. to Oct. 1993, and Apr. to Oct. 1994. These diameters were converted to trunk cross-sectional area (TCSA) for statistical analysis. The entire data set was analyzed with the GLM procedure (SAS Institute, Cary, N.C.) as a split-plot in time, where measurement date was the subplot. Because some trees died during the study, there were missing observations, and repeated measures analysis could not be performed. Because the treatment $x$ date interaction was significant $(P \leq 0.001)$, data for each date were analyzed as a randomized complete-block design, and single-degree-of-freedom contrasts were used to compare selected treatments.

\section{Results and Discussion}

After 3 years, TCSAs of young pecan trees grown in weed-free conditions were significantly larger than those of trees grown with a cover crop $(P \leq 0.001)$ (Fig. 1). Mean TCSA of weed-free trees increased 26.1-fold after the third growing season but increased only 13.2fold for trees grown with any cover crop (Table 1).

To test the interactive effects of treatment and time, another analysis was performed on the entire data set, where treatments were designated as weed-free or cover crop. The sums of squares due to the main effect of time and treatment $\times$ time interaction were partitioned into single-degree-of-freedom orthogonal polynomials. There was a significant treatment $\times$ time (linear) interaction, indicating that TCSA increased linearly over time and tree trunks of weed-free trees grew faster than trunks of trees grown in covers crops (Fig. 1).

Growth differences occurred early in the experiment. By Mar. 1993, the mean TCSA of the weed-free trees was $4.3 \mathrm{~cm}^{2}$ compared to $3.2 \mathrm{~cm}^{2}$ for the cover crop trees $(P \leq 0.05)$. By June 1993, the mean TCSA of the trees in weed-free plots was $6.0 \mathrm{~cm}^{2}$ compared to 4.2 $\mathrm{cm}^{2}$ for trees with cover crops $(P \leq 0.01)$.

Table 1. Effects of orchard floor crops on trunk cross-sectional area (TCSA) of young pecan trees.

\begin{tabular}{|c|c|c|c|c|}
\hline \multirow[b]{2}{*}{ Crop } & \multicolumn{4}{|c|}{ Mean TCSA $\left(\mathrm{cm}^{2}\right)^{z}$} \\
\hline & Initial & 13 Sept. 1992 & 19 Oct. 1993 & 11 Oct. 1994 \\
\hline Cover crops $^{y}$ & 2.0 & 2.9 & 9.8 & 26.4 \\
\hline Weed free & 1.9 & 3.7 & 18.9 & 49.6 \\
\hline Significance & & & & \\
\hline $\begin{array}{l}\text { Treatment }(\mathrm{T}) \\
\mathrm{T} \times \text { month }\end{array}$ & & $\begin{array}{l}\mathrm{NS} \\
* * *\end{array}$ & $* *$ & $* *$ \\
\hline Grasses vs. legumes & & NS & NS & NS \\
\hline $\begin{array}{l}\text { Summer legumes vs. } \\
\text { winter legumes }\end{array}$ & & NS & NS & NS \\
\hline Weed free vs. nutsedge & & NS & $* *$ & $* *$ \\
\hline Weed free vs. cover crops & & NS & $* * *$ & $* * *$ \\
\hline
\end{tabular}

${ }^{\mathrm{Z}}$ Initial = 1 May 1992; other dates: after first second and third seasons

${ }^{y}$ Winter legumes: hairy vetch, common vetch, arrowleaf clover; summer legumes: buckwheat and hairy indigo; summer perennials: bahiagrass, common bermudagrass, centipedegrass, and yellow nutsedge.

Ns, **,****Nonsignificant or significant at $P<0.001$ or 0.01 , respectively. 
Trunk sizes of trees grown with the various cover crops were similar, but those of trees grown under weed-free conditions were larger than those grown with nutsedge competition by the end of the second season (Table 1). Nutsedge is of special interest as a weed because low rates of glyphosate eliminate species that compete with nutsedge.

In this study young pecan trees under weedfree conditions grew faster than those subjected to competition, regardless of the competing species. Patterson and Goff (1994) reported initial production of trees grown without weed competition was enhanced. In their study, trees grown in a weed-free environment yielded $2204 \mathrm{~kg} \cdot \mathrm{ha}^{-1}$ through the seventh growing season. Conversely, trees grown with no weed control yielded only $394 \mathrm{~kg} \cdot \mathrm{ha}^{-1}$ of pecans over the same time period. Our research demonstrates that a broad range of competing species has similar effects: all cover crops appear to reduce growth, and probably yield, substantially.

With the high cost of establishing a pecan orchard, early and abundant yields are important. Weed-free strips within the dripline of young pecan trees may help accomplish early yields (Patterson and Goff, 1994). However, a system of growing cover crops in the tree row middles, while keeping the area immediately surrounding the young trees weed free, appears to benefit young trees without impairing benefits derived from cover crops.

\section{Literature Cited}

Blackmon, G.H. 1948. A cover crop program for pecan orchards. Proc. Southeastern Pecan Growers' Assn. 41:43-48.

Bugg, R.L., M. Sarrantonia, J.D. Dutcher, and S.C.

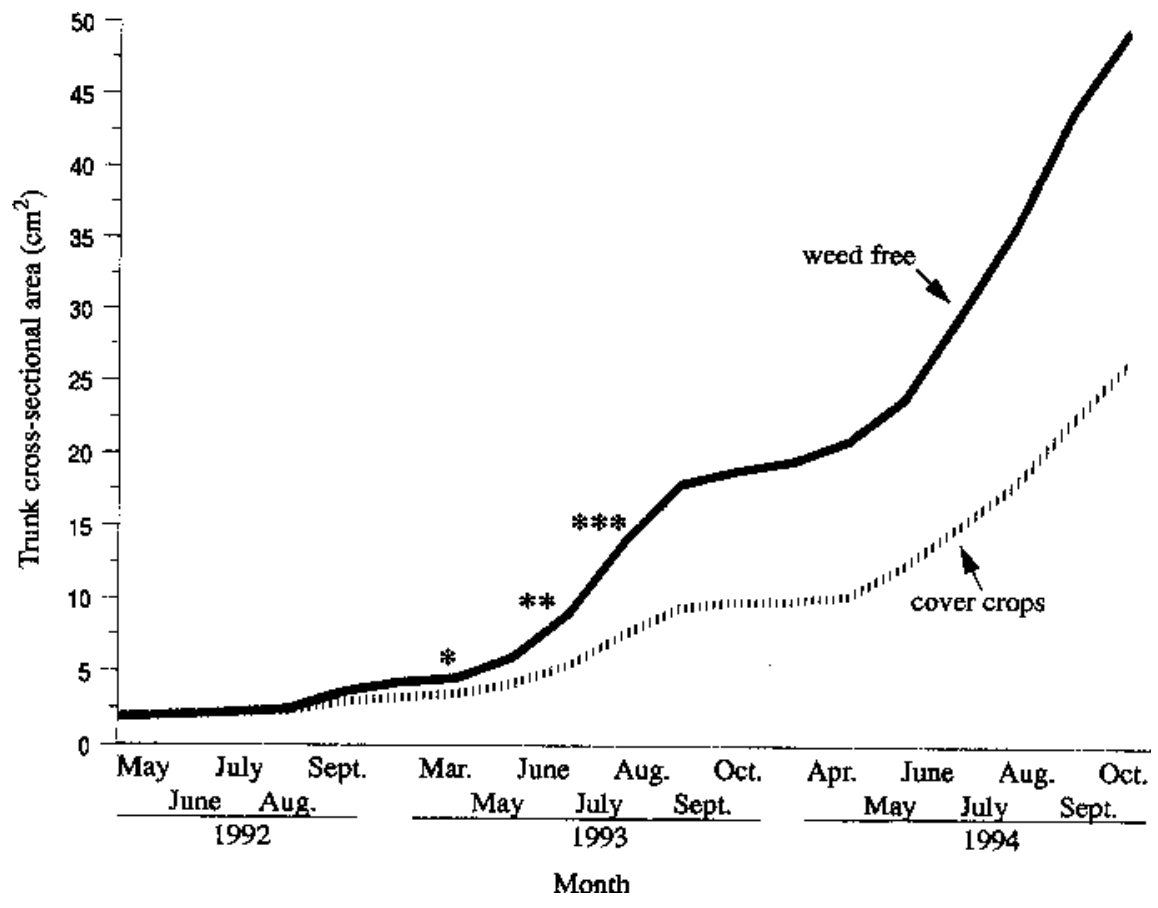

Fig. 1. Trunk cross-sectional area of 'Desirable' pecan trees in the first three growing seasons where vegetation was controlled ( - and where cover crops were grown ( 11 PIIII). Significant at $P$ $\leq 0.05,0.01$, or 0.001 ; where astericks appear is the first point at which significance occurs.

Phatak. 1991. Understory cover crops in pecan orchards: Possible management systems. Amer. J. Alternative Agr. 6:50-62.

Hardy, M.B. 1939. Cultural practices for pecan orchards. Proc. Southeastern Pecan Growers' Assn. 33:58-64.

Patterson, M.G. and W.D. Goff. 1994. Effects of weed control and irrigation on pecan growth and yield. Weed Technol. 8:717-719.

Patterson, M.G., G. Wehtje, and W.D. Goff. 1991. Effects of weed control practices and irrigation on the growth of young pecans. Weed Technol. 4:892-894.

White, A.W., Jr. 1981. Legumes for supplying nitrogen and studies on legumes in pecan orchards. Pecan South 8(4):24-31. 